\title{
Liquid polymers keep drip irrigation lines from clogging
}

\author{
J. L. Meyer $\square \quad$ M. J. Snyder $\square \quad$ L. H. Valenzuela $\quad \neg \quad$ A. Harris \\ R. Strohman
}

line pressure. In fact, that change in pressure can indicate a substantial decrease in water emission.

Injection of fertilizers into the drip system can enhance clogging. Fertilizers that contain calcium and phosphates have the greatest potential to clog. In contrast, liquid fertilizers containing acids can help prevent lime deposition.

The traditional method for controlling calcium and magnesium carbonate deposits has been to inject acid into the system either continuously or intermittently to reduce the $\mathrm{pH}$ of waters. The compound used most commonly to lower the $\mathrm{pH}$ of water has been sulfuric acid. Hydrochloric and phosphoric acids have also been used, but they are more expensive and pose severe handling hazards.

The search for a calcium and magnesium carbonate inhibitor led researchers to examine several commercial products. One of these is the patented homopolymer of maleic anhydride that we studied in 1989 in a strawberry drip system.

\section{Field experiments: 1988-1989}

In November 1988, we selected Gold Coast Farms of Santa Maria for the January-toAugust 1989 trial. Theirwell water contained bicarbonate levels in the 4.0 to $4.5 \mathrm{Meq} / \mathrm{L}$ range. Within the farm, we divided a 10-acre Chandler strawberry field into four plots of 2.5 acres each. Two plots used the maleic anhydride polymer injected at $2 \mathrm{mg} / \mathrm{L} \mathrm{(2}$

\section{Chemical clogging}

Irrigation waters, particularly the well waters of coastal and southern California, contain varying amounts of soluble salts that may precipitate in drip lines or emitters. As water evaporates, temperatures change in the lines, the concentrations of solutes increase, and some solutes can precipitate with increased temperature. High levels of calcium, magnesium, bicarbonate, and sulfates are of particular concern in the West. Calcium, together with bicarbonates and sulfates, can form precipitates of lime and gypsum downstream from a filter, clogging drip orifices. Clogging may be partial or complete. In the case of a partial clog, the only apparent change is a small increase in

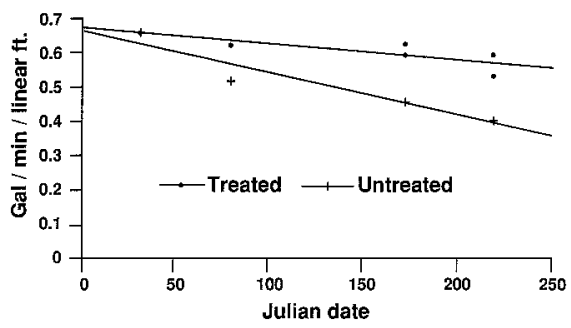

Fig. 1. Drip tubing flow rates decrease as the season progresses. Extra clogging in the lines not treated with the liquid polymer significantly reduces their capacity to transport water to plants ( $1 \%$ level).

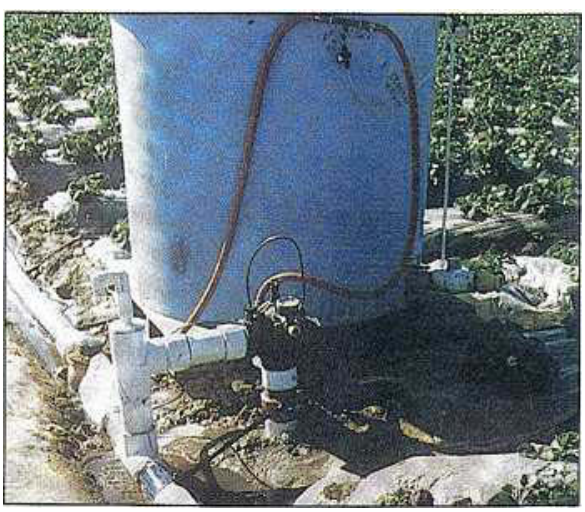

This apparatus injects an experimental polymer into drip lines, inhibiting the buildup of lineclogging sediments.

ppm) and continuous chlorine at $1 \mathrm{mg} / \mathrm{L}$, and the other two plots used only continuous chlorine injection.

The 10-acre field was set up so each of the four sections would irrigate separately. Each section consisted of one hundred 300-footlong rows. Water meters were installed for each plot. The grower continuously injected chlorine into each irrigation system from February 1, 1989 through August 8, 1989. The treated plots also received a continuously injected polymer treatment. The grower used soil matrix potential tensiometers to determine irrigation scheduling. Irrigation was initiated when tensiometers reached $15 \mathrm{cb}$ readings at depths of 4 or 6 inches.

\begin{tabular}{|c|c|c|c|c|}
\hline \multicolumn{5}{|c|}{$\begin{array}{l}\text { TABLE 1. Applied water and reference } \\
\text { evapotranspiration, Gold Coast }\end{array}$} \\
\hline \multirow[b]{2}{*}{ Month } & \multicolumn{3}{|c|}{ ETaw* } & \multirow[b]{2}{*}{ ETot } \\
\hline & \multicolumn{2}{|c|}{ Treated } & Untreated & \\
\hline & \multicolumn{3}{|c|}{ ave. inches applied } & inches \\
\hline March & \multicolumn{2}{|c|}{3.26} & 3.33 & 3.62 \\
\hline April & \multicolumn{2}{|c|}{2.92} & 2.92 & 5.08 \\
\hline May & \multicolumn{2}{|c|}{4.81} & 4.33 & 5.83 \\
\hline June & \multicolumn{2}{|c|}{4.30} & 4.41 & 4.94 \\
\hline July & \multicolumn{2}{|c|}{4.09} & 4.00 & 5.84 \\
\hline Total & \multicolumn{2}{|c|}{19.38} & 18.99 & 25.31 \\
\hline \multicolumn{5}{|c|}{$\begin{array}{l}\text {-ETaw = the evapotranspiration of applied water. } \\
\text { †ETo = reference evapotranspiration from CIMIS sta- } \\
\text { tions. }\end{array}$} \\
\hline \multicolumn{5}{|c|}{$\begin{array}{l}\text { TABLE 2. Irrigation hours to meet crop water } \\
\text { requirement }(E T c) \text { for strawberry at } \\
\text { Santa Maria, } 1989\end{array}$} \\
\hline Month & \multicolumn{2}{|c|}{ Treated } & Untreated & Difference \\
\hline March & \multicolumn{2}{|c|}{20.45} & 20.45 & .00 \\
\hline April & \multicolumn{2}{|c|}{27.75} & 28.12 & .37 \\
\hline May & \multicolumn{2}{|c|}{29.16} & 33.61 & 4.46 \\
\hline June & \multicolumn{2}{|c|}{27.40} & 35.74 & 8.34 \\
\hline July & \multicolumn{2}{|c|}{28.36} & 37.16 & 8.80 \\
\hline Total & \multicolumn{2}{|c|}{133.12} & 155.08 & 21.97 \\
\hline \multicolumn{5}{|c|}{$\begin{array}{l}\text { TABLE } 3 \text {. Strawberry yield, measured in } 12 \text { - } \\
\text { pound crates per } 2.5 \text { acres, Gold Coast, } 1989\end{array}$} \\
\hline Treatme & & $\begin{array}{l}3 / 3 \text { to } \\
5 / 19\end{array}$ & $\begin{array}{c}5 / 20 \text { to } \\
8 / 20\end{array}$ & $\begin{array}{l}\text { Total } \\
\text { for year }\end{array}$ \\
\hline Treated & & 4,797 & 2,661 & 7,458 \\
\hline Treated & & 4,264 & 2,365 & 6,629 \\
\hline Untreate & East & 4,165 & 2,310 & 6,475 \\
\hline Untreate & Vest & 4,120 & 2,288 & 6,408 \\
\hline
\end{tabular}


We read the water meters about once a week. Emitter flow and uniformity were measured on March 21, June 21, and August 7. Yield data were taken for each plot from March through May. Weekly and monthly reference evapotranspiration (ETo) data were obtained from the CIMIS weather stations in Santa Maria.

\section{Results}

The applied water data (ETaw, table 1) showed a trend of lower flow rates in the untreated plots. Figure 1 shows the flow rates of polymer-treated and untreated waters on March 1, March 21, June 21, and August 7. Emission evaluations of polymertreated water show only slight decreases over the 6-month growing period, but untreated well waters show a decrease of nearly $50 \%$ by August. A linear regression of flow rate versus time was fitted for both treated and untreated plots. The test for equality of slopes demonstrated that the decrease in flow rate over time for untreated water was significantly greater than for treated water at the $1 \%$ level.

\section{Conclusions}

The results (table 1, fig. 1) indicate that the system injected with $2 \mathrm{mg} / \mathrm{L}$ maleic anhydride polymer supplied the actual amount of water required for plant needs, while the untreated tubing's output decreased as the season progressed. The crop water requirement (ETc) for strawberries and the flow rate differences are shown as hours of irrigation in table 2. The hours of irrigation needed to apply a given amount of seasonal water are much greater for the untreated than the treated system.

The yield from each individual plot was obtained for the period from March 1989 to May 19, 1989, and the yields from the aggregated plots (10 acres), from May 20 to August 20, 1989 (table 3). A yield increase of about 300 12-pound trays per 2.5 acre plot was obtained in the early season. Assuming this trend continued, an overall yield increase of about 600 trays would result where the aggregated yield was assigned to each 2.5 acre plot and added to the early season results. This suggests that the plots treated with $2 \mathrm{mg} / \mathrm{L}$ maleic anhydride polymer received the appropriateamount of irrigation water. Yields were increased and drip efficiency improved where we injected the polymer into drip irrigation lines.

J. L. Meyer is Irrigation and Soils Specialist and R. A. Strohman is Staff Research Associate, UC Riverside; M. J. Snyder is Farm Advisor, Santa Barbara County;L.H. Valenzuela is Farm Advisor, Santa Barbara County; and A. Harris is with Ciba-Geigy, Manchester, United Kingdom.

Theauthorswish toacknowledge the valuable assistance provided by growers Ronald Burkand Robert Espiñola of Gold Coast Farms, and by Olocco Ag Services, Santa Maria, California.

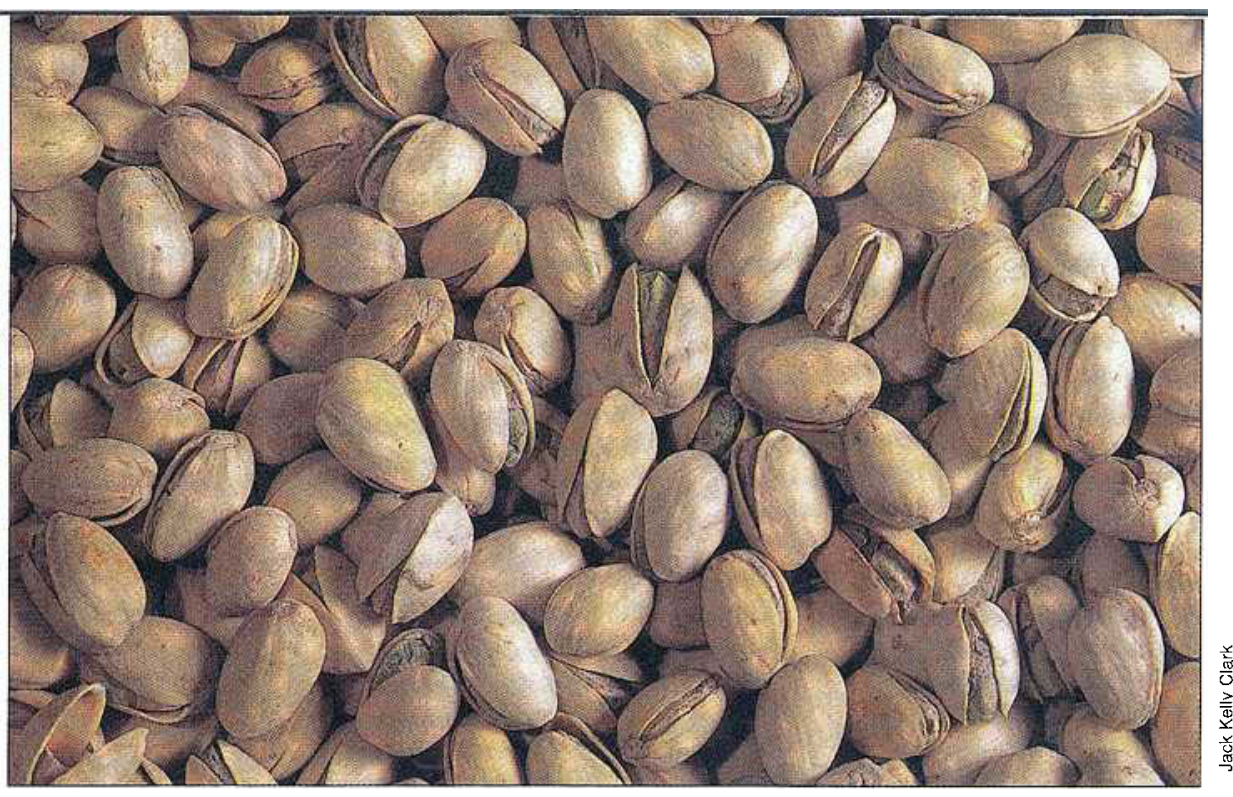

\title{
A shoppers' survey: California nuts and produce, food quality, and food safety
}

\author{
Marciel A. Pastore $\square \quad$ Christine M. Bruhn
}

795 consumers interviewed at 53

California markets gave a variety of reasons for buying the way they do. Many had their own ideas about what indicates good quality in produce, but had trouble putting those ideas into words. Consumer ideas about food safety were easier to articulate.

Consumer interest in fresh produce is high. Researchers report that people are changing their eating habits to increase their intake of produce, and this attitude is reflected in different purchasing patterns.

The guiding factors in food choice are quality, nutritive value, and safety. Consumer concerns about produce safety primarily with respect to pesticide and chemical residues - have been the focuses of recent research. When specifically asked, about $80 \%$ of consumers in a nationwide survey considered residues to constitute a serious hazard. In the past two years, almost $20 \%$ of consumers have transformed their concern into action, and have altered their purchasing patterns to include the purchase of organicorcertified "residue-free" produce.

Little research focusing on consumers' perception of quality has been completed. Consumers have identified products that are "inconsistent" in quality, but their criteria for quality have not been identified. Although brand-name produce has been available for some time, consumers do not place a lot of emphasis on brands when it comes to purchasing. Fewer than half of consumers consider a brand-name item to be superior in quality to those without brands. Other researchers havenotmeasured the influences of consumer identification and use of other indicators of producequality, such as color, texture, and stage of maturity.

We undertook this study to determine the selection criteria of California consumers and their attitudes toward specific California specialty crops.

\section{Method}

The first author personally interviewed 795 consumers in an open-ended questionnaire at 53 sites throughout California. Cities were selected at random within population parameters. Six stores were selected as interview sites in each of five cities with populations over 50,000 (Citrus Heights, Fremont, Los Angeles, Ontario, and San Bernardino). We selected three stores from each of five cities, unincorporated areas, or polling districts with populations between 500 and 50,000 (Carmichael, Santa Cruz, San Gabriel, Citrus Heights, and Cardiff by the Sea). We also selected one store in each of eight cities or unincorporated areas with populations under 500 . Stores were randomly selected from the telephonedirectory. Weconducted interviews in the produce department of each store between February and July 1987. Fifteen consumers were randomly selected for interview at each survey site.

Consumers wereasked to recall thenumber of times they had purchased selected 